\title{
U KOLOPLETU (POST)MODERNOSTI: STUDENTSKA PERSPEKTIVA BRZE I ETIČKE MODNE POTROŠNJE
}

\author{
Ivana Brstilo Lovrić, Marta Šuća i Paula Zujić
}

\author{
Odjel za sociologiju \\ Hrvatsko katoličko sveučilište \\ Ilica 242, 10000 Zagreb \\ e-mail: ivana.brstilo@unicath.hr
}

\begin{abstract}
Sažetak
Ovaj rad tematizira nedovoljno istraženu modnu potrošnju iz hrvatskoga konteksta. S obzirom na to da je u referentnoj literaturi istaknut aktivni modni interes studenata, njih 24 uključeno je u provedbu kvalitativnoga istraživanja metodom fokus grupe održane u četiri navrata sredinom 2020. Opći cilj bio je istražiti studentske modne prakse u svakodnevici s posebnim osvrtom na principe brze i etičke modne potrošnje kako bi se utvrdilo prema kojem se modelu profiliraju. Iako sudionici istraživanja nisu raspolagali s konkretnim saznanjima o (ne)etičnim praksama modnih trgovina te su u pravilu konzumirali brzu modu, iskazali su otvorenost naspram etičkih proizvoda smatrajuci kako moda ne bi trebala biti platforma ugnjetavanja uključenih aktera. Nalazima je detektirano i postojanje (post)modernoga potrošačkoga sukoba tako što su se sudionici okarakterizirali modnim individualistima koji su istodobno slijedili modne trendove uz opće negiranje utjecaja na vlastite potrošačke izbore dok su se u većini inspirirali modnim sadržajima s društvenih mrě̌a, iz okoline te iz različitih medija. Razvivši listu modnih ulaganja kombinirali su kvalitetu i kvantitetu, nerijetko se otkrivajući masovnim ekskluzivistima. Pokazana slojevitost i hibridnost studentske modne potrošnje u konačnici je interpretirana u kontekstu (post)moderne životno-stilske ambivalentnosti te je ukazana potreba za većom edukacijom i drustvenim angažmanom studenata na ovu temu.
\end{abstract}

Ključne riječi: modna potrošnja, brza i etička moda, studenti, Hrvatska, (post)modernost.

\section{UVOD}

U perspektivi suvremenoga društva brojni društveni analitičari istaknuli su različite napetosti, kontradikcije i ambivalentnosti. Među njima je i Lipovetsky (2008) koji smatra da je suvremenost isprepletena različitim suprotnostima poput apostrofiranja kritičkog duha i hedonističkih aspiracija, orijentacije na kvalitetu i glorifikacije brzine, nostalgičnih formi i impulsa novina. Takve su suprotnosti i proturječja krajnje funkcionalni, smatra autor, jer (pret)postavljaju uvjet društvenoga razvoja orijentiranoga na potrošnju treće faze. Riječ je o tekućoj fazi takozvane hiperpotrošnje obilježene klasno pokretljivim potrošačem čije su želje, izbori i imaginacije ključne vodilje potrošačkoga izbora, a onda i kreiranja vlastitog života. Takav subjekt ne može se ukalupiti u ideal tipske formacije kakav bi bio puki konzumeristički obruč ugode i zabave. Odatle „cijepanje“ hiperpotrošnje na funkcionalnu potrošnju orijentiranu na praktične stvari uz nerijetko 
praćenje zamorom (potrošnja-tlaka) te zabavnu potrošnju koja funkcionira kao odmak od svakodnevice u dijapazonu materijalnih i iskustvenih proizvoda (potrošnja-svečanost). Također, iako u bitnome individualistička, emocionalna i hedonistička, suvremena potrošnja postaje karakteristični adresat tema općega dobra, društvene odgovornosti i socijalne pravde. „Otud 3. faza funkcionira prema dvjema suprotnim logikama, jer se ludička potrošnja razvija paralelno $s$ tjeskobnom ili opreznom potrošnjom (kvaliteta proizvoda, opasnost robe, GMO itd.)" (Lipovetsky, 2008:42). U toj se dinamici po autoru i krije perpetuum mobile suvremenoga potrošačkoga društva za koje pretpostavlja da i može postojati samo kroz suprotstavljena načela i proturječnosti. Takvi rezovi ne čude Baumana (1993) koji je ustvrdio da ambivalencija i moralna dvojakost napreduju s razvojem modernosti, istodobno padajući na leđa pojedinca. $S$ obzirom na nikad razgranatiju ponudu u kojoj su svi izbori legitimni, a svi autoriteti jednako (ne)moćni da bi predstavljali nepokolebljiv oslonac i izvor sigurnosti, pojedinci ne mogu nadvladati stanje nesigurnosti, već je potrebno naučiti živjeti s njime. Izbor pri tome više nije odabir ili kršenje jednog skupa pravila, jer ista ne postoje kao jedinstvena, već kao kategorija pluralizama. „U kompleksnoj mreži međusobnih ovisnosti posljedice svakog čina ambivalentne su - nijedan čin, bez obzira koliko plemenit i nesebičan i blagotvoran nekome, ne može spriječiti moguću štetu onima koji su se mogli naći, nepažnjom, na njegovu kraju. Ambivalencija se konstantno generira i obnavlja oprečnim pritiscima socijalizacije i društvenosti, normama koje čuvaju društveni prostor i moralnim težnjama koje stvaraju moralni prostor" (Bauman, 2009:225).

O nesigurnostima i ambivalentnostima visoke ili refleksivne modernosti piše i Giddens (1991) kroz sliku odbjegloga motora goleme snage (engl. juggernaut). Iako se nekada čini da isti ima predvidljivu putanju, podložan je vrludanju u nepredvidljivim smjerovima. S obzirom da je strukturalno (po)složen od različitih komponenti i suprotstavljenih komandi, može se ustvrditi da je inherentno kontradiktoran i utoliko predstavlja izvor konstantnih rizika koji su samo djelomično pod ljudskom kontrolom. Njegov su put i tempo krajnje neizvjesni, prožeti uzbuđenjima i anticipacijom nade, što onda dovodi do ambivalentnog koegzistiranja ljudske ontološke sigurnosti i egzistencijalne anksioznosti. Ta se dvosložnost prenosi fenomenologijom modernosti čija su četiri dijalektička okvira opisana u presjecima suprotnosti. Među njima razmještanje i ukorjenjivanje predstavlja presjek otuđenja i familijarnosti; intimnost i impersonalnost presjek je osobnog povjerenja i neosobnih veza; ekspertiza apstraktnih sustava i njihovo prisvajanje je presjek apstraktnih sistema i svakodnevnoga znanja; privatnost i angažman je presjek pragmatičnoga prihvaćanja i aktivizma (Giddens, 1991:139-140). Istaknuti fenomenološki okviri modernosti doprinose rastrganosti i rascjepu koji suvremenoga pojedinca uvlače u mrežu ambivalentnih utjecaja oko kojih se onda nastoji smisleno organizirati u svakodnevici. Odatle fokus jedne strane na osobnu sferu i privatne stvari, jer vlada mišljenje da pojedinac na društvenom planu ne može učiniti mnogo, dok se na drugoj strani potencira osobni angažman i naglašena potreba mijenjanja stvarnosti.

Jedno od aktualnih društvenih polja na kojima se pojedinci nastoje konfrontirati s tekućim društvenim izborima, rizicima i problemima je sve popularnija niša etičke potroš- 
nje. Njome se promovira društvena odgovornost poduzeća koja poštuju prava radnika, ne zagađuju okolišs, ne koriste dječji rad ili ne vrše testiranja na životinjama. Mladenački revolt u suvremenomu društvu po Lipovetskom (2008:216) upravo u takvim temama nailazi na svoj zamah pa se kroz opiranje različitim društvenim represijama u „normama potrošnosti i tradicionalnoga morala" događa oslobođenje osobne autentičnosti. Međutim, mladi su s druge strane pragmatični konzumenti brze mode kojoj je karakteristika masovno cirkuliranje trendovskih linija odjeće koje se sa stajališta zaštite okoliša smatraju neodrživima i neetičnima što onda njihove potrošačke prakse čini slojevitima.

Ovaj se rad upravo bavi modnom potrošnjom mladih u Hrvatskoj s naglaskom na aspekte etičke i brze mode kako bi se doznalo kojem su modelu skloniji ili se radi o njihovom kombiniranju. Na taj se način perspektive mladih u Hrvatskoj stavljaju u širi društveni kontekst koji neki autori dovode u vezu sa stadijima visoke modernosti ili postmodernosti koji inkliniraju ambivalentnosti, a za koje pretpostavljamo da se reflektiraju i u njihovoj modnoj potrošnji.

Sukladno naznačenoj temi, ovaj je rad organiziran prema sljedećoj strukturi. Nakon uvodnoga predstavljanja ključnih odrednica (post)modernih narativa kao teorijskih polazišta ovoga rada, slijedi detaljnija teorijska razrada modne potrošnje s naglaskom na pojmove brze i etičke mode u kombinaciji s povezanim istraživanjima, a potom se predstavlja korištena metodologija istraživanja. Naime, s ciljem dubinskog razumijevanja mladenačke modne potrošnje koja nije dovoljno istražena iz hrvatskog konteksta, a koja je predmet aktualnih globalnih rasprava u akademskom svijetu i društvenoj javnosti, odlučeno je da se provede detaljno istraživanje. Mladi, točnije njihova podgrupacija studenata u Hrvatskoj odabrana je za sudionike fokus grupa s obzirom da je u referentnoj literaturi istaknuta njihova modna aktivnost i osviještenost (Su i Chang, 2018; Cook i Yurchisin, 2017; Joung, 2014; Joergens, 2006). Dobiveni istraživački nalazi o studentskim stavovima i praksama u modnoj potrošnji detaljnije su izloženi u sekciji analize i interpretacije nakon koje slijede njihova zaključna razmatranja. Slijedi dakle razrada teme modne potrošnje u kontekstu brze i etičke mode.

\section{BRZA I ETIČKA MODA}

Suvremenu modnu industriju zadnjih desetljeća karakterizira niz strukturalnih promjena koje su dovele do smanjenja robnih cijena, fleksibilnosti dizajna, brzine isporuke. Od posebnog značaja pokazala se suradnja s vanjskim dobavljačima, u pravilu s državama niskih troškova rada, što je $s$ implementacijom tehnika poslovanja u realnom vremenu, strategija agilnosti i brzog odgovora među ključnim instancama opskrbnog lanca podebljalo učinkovitost operacijskih performansi. U usporedbi sa suvremenim modelom, tradicionalna je modna industrija do osamdesetih godina 20. stoljeća prakticirala dugotrajno vremensko predviđanje trendova i potražnje unutar faza dizajniranja i plasiranja konfekcijskih linija, njihovog masovnog prihvaćanja te zastarijevanja. Ključna modna događanja bila su modni sajmovi, izložbe tkanina i modne revije u okviru godišnjih kolekcija proljeće-ljeto ili jesen-zima. Od devedesetih godina 20. stoljeća u bitnome je 
skraćen životni ciklus mode, između ostaloga i uvođenjem međusezona čime je intenziviran pritok nove robe, kao i mogućnost bržega plasiranja modnih trendova. $S$ time su višemjesečni standardi robnoga kreiranja i distribuiranja po tradicionalnom kolekcijskom modelu zamijenjeni prototipovima malih i raznolikih marža koje se unutar nekoliko tjedana dostavljaju spremnima za izloge i vješalice trgovina (Joung, 2014: 688-689; Bhardwaj i Fairhurst, 2010:165-168; Barnes i Lea-Greenwood, 2006:259-263).

Prijelaz na diferencirani modni model pokazao se iznimno profitabilnim u sustavu takozvane brze mode. Riječ je o pojmu koji obuhvaća povoljne, trendovske i potrošne linije odjeće koje su osobito popularne među mladima (Su i Chang, 2018; Cook i Yurchisin, 2017; Joy i sur., 2012; Bhardwaj i Fairhurst, 2010; Barnes i Lea-Greenwood, 2006).

U njihovom odnosu zamjetne su dvostruke tendencije, ujedno ključne karakteristike sustava brze mode. Jedna je zadovoljavanje mladenačke potrebe za individualiziranim stilovima baziranima na pristupačnoj modi koja se može često obnavljati (Su i Chang, 2018). Naime, s obzirom da sustav brze mode funkcionira u malim maržama s povoljnim cijenama, potrošači su motivirani za njihovu kupovinu i bez čekanja sniženja (Cook i Yurchisin, 2017) po principu „uzmi sada ili žali kasnije“" (Bhardwaj i Fairhurst, 2010:166) na osnovu čega je moguće kreiranje instant $i$,in“ stila sukladno postmodernoj fenomenologiji promjenjivih identiteta (prema Joy i sur., 2012:276). Druga stavka tiče se posljedičnoga stvaranja kontradiktorne forme masovne ekskluzivnosti (Joy i sur., 2012:275) koja opravdava kolokvijalni izraz volim sve sto vole mladi odnosno, odijevam se kao i većina vršnjaka. $\mathrm{Na}$ tragu je ovih pojmova takozvani (post)moderni potrošački sukob za koji su neke istraživačice ustanovile da se osobito aplicira na mlade ljude koji se u procesu konstrukcije potrošačkih identiteta nalaze u procijepu individualizma i uklapanja u društvo pa se, primjerice, prezentiraju individualistički orijentiranim potrošačima, dok istodobno prate modu i slijede modne trendove (Wilska i Pedrozo, 2007:349). Mladima omiljena, a tržišno vodeća trgovina brze mode španjolska je grupa Inditex u čijem je vlasništvu Zara s 3.000 trgovina u 96 zemalja (Dockrill, 2020) i 24 nove kolekcije odjeće godišnje (Remy i sur., 2016:2) te švedski H\&M koji posluje u 62 zemlje svijeta (Robertson, 2020) s 12 do 16 kolekcija odjeće godišnje koje se tjedno osvježavaju (Remy i sur., 2016:2). Prema općim analizama, trgovine brze mode u odnosu na tradicionalne maloprodajne trgovine bilježe globalni poslovni rast $s$ prosječnim razlikama u profitnim maržama 16\% naspram 7\% (Cook i Yurchisin, 2017:144; Su i Chang, 2018:91; Joung, 2014:689; Joy i sur., 2012:276). Primjerice, Zara čak i u izazovnim okolnostima gospodarske krize te prilagođavanja promjenjivim potrošačkim navikama generira profit u milijardama dolara zahvaljujući „poslovnom modelu stroge kontrole proizvoda u cijelom lancu opskrbe i brzom reagiranju na trendove zbog kratkog vremena od dizajniranja do proizvodnje" (Laudette i Dowsett, 2019). Ne čudi stoga što se takozvanu brzu modu naziva McModom ili McFashion (Joy i sur., 2012) sukladno Ritzerovoj (1999) tezi o profitabilnosti „mekdonaldiziranih“ sustava kojih su istaknute dimenzije u sustavu brze mode učinkovitost, brzina usluge i primat kvantitete.

Valja istaknuti kako je uspon brze mode u vezi s promjenom profila potrošača koji se prije samo nekoliko desetljeća nisu smatrali osobito modno osviještenima (Bhardwaj i 
Fairhurst, 2010:166) da bi u novije vrijeme porastao njihov interes za trendovskim proizvodima i stilovima (Barnes i Lea-Greenwood, 2006) uz redovno posjećivanje modnih trgovina (Joy i sur., 2012). Tome je značajan obol dala popularna kultura promovirajući modne trendove te oblikujući potrošačke ukuse putem medija televizije, glazbe, filma, tiskovina, reklama, poznatih osoba i drugih izvora ${ }^{1}$ (Barnes i Lea-Greenwood, 2006:260-261).

Neke od navedenih stavki potvrdilo je istraživanje Morgan i Birtwistle (2009) u kojemu su sudionice istaknule da kupuju više nego što su to prije radile, u prosjeku svaka dva tjedna ili u tijeku mjesec dana $U$ tome su prednjačile mlađe žene koje su još češće obnavljale vlastitu garderobu, a uz to su pratile modne sadržaje poput magazina o modi i slavnim osobama te su davale prednost brojnijim i jeftinijim komadima odjeće naspram jednog skupljeg komada. Sudionice istraživanja uglavnom nisu imale konkretnu predodžbu koliko dugo zadržavaju odjeću, a kao razloge za prestanak nošenja jeftinije odjeće navele su lošiju kvalitetu, nove modne trendove ili odjevne predmete za posebne prilike.

Navedene prakse i promišljanja idu u korak s općim trendovima po kojima se od 2000. do 2014 . udvostručila proizvodnja odjeće te je za $60 \%$ porastao broj odjevnih predmeta koje prosječan potrošač godišnje kupuje. Uz to, u gotovo svakoj kategoriji odjeće, potrošači su odjeću zadržali upola kraće nego prije 15 godina, odbacujući je nakon sedam do osam nošenja te je tretirajući gotovo kao da je za jednokratnu upotrebu (Remy i sur., 2016:2). To je poduprlo istraživanje Joung (2014) prema kojemu su studentski potrošači brze mode skloniji odbacivanju, a ne recikliranju, moguće i zbog percepcije niže kvalitete takve odjeće: „S obzirom da je takva odjeća napravljena od jeftinih materijala, nije rijetkost da je potrošači nose jednom ili dva puta prije nego je odbace. Ponekad to nije stvar izbora, jer je roba toliko loše napravljena da se raspadne nakon jednog nošenja. Brza moda prodaje se i proizvodi za nošenje manje od deset puta", zaključuje Joung (2014:689).

Iz te perspektive brza moda često se kvalificira jednokratnom (Morgan i Birtwistle, 2009) i neodrživom modom (Joy i sur., 2012) koja na globalnoj razini povećava stvaranje otpada (Bhardwaj i Fairhurst, 2010). S time je povezana sve češća kritika potrošača naspram pune cijene modne industrije jeftine i trendovske ponude (Roubík i Mazancová, 2017), kao i utjecaja konzumiranih proizvoda na vlastiti izgled i zdravlje (Hall, 2011) te različite društvene aktere i razine socijalne stvarnosti (Brstilo i sur., 2016).

Termin etičke potrošnje ujedinjuje slične tendencije usmjerene na prava radnika, društveno odgovorna poduzeća, zaštitu okoliša, dobrobit životinja i srodne teme od šireg društvenoga značaja (Roubík i Mazancová, 2017; Lewis, 2012; Hall, 2011; Joergens, 2006). Jedan je od ključnih programa etičke mode privlačenje mladih i masovnih po-

$1 \mathrm{U}$ recentnije vrijeme svjedočimo i fenomenu takozvanih internetskih influencera (Bohra i Jose, 2019) koji postaju sve značajniji anticipatori modnih trendova putem društvenih mreža poput Instagrama (de Perthuis i Findlay, 2019). 
trošača da nabavljaju odjeću u skladu $s$ „etičkim načelima koji omogućuju dobre radne standarde i uvjete te omogućuju održiv poslovni model u zemljama porijekla odjeće" te poticanje modne industrije na veće korištenje organskih, biorazgradivih materijala $s$ minimalnim efektom na okoliš (Joergens, 2006:361). Stoga se, za razliku od kvantitativnoga i trendovskoga pristupa brze mode, etička varijanta preklapa s terminima spore, održive, ekološke, zelene, angažirane, društveno odgovorne, osviještene mode (Brstilo i sur., 2016; Aishwariya, 2019). ${ }^{2}$

Iako se u literaturi navodi da su upravo mladi nove generacije etički potrošači, iz pregleda tematskih istraživanja primijećena je njihova etička ambivalentnost. Tako je istraživanje Carrigan i Attalla (2001) otkrilo da na mladenačke potrošačke prakse nije u bitnome utjecala informiranost o slabim ili kontroverznim „etičkim dosjeima“ pojedinih modnih poduzeća. Takve primjere zbog njihovih ekonomskih doprinosa zemljama u razvoju nisu osudivali niti su ih bili spremni bojkotirati. U vezi s tim istaknuli su da kupuju određene modne proizvode prvenstveno zato jer im se sviđaju, a ne zbog njihove etičke atribucije, ali i da bi medijska izvještavanja o takvim primjerima mogla potencirati njihovu veću etičku zauzetost u potrošnji. Pokazalo se i da imaju listu etičkih prioriteta na vrhu koje su prava životinja, a na dnu eksploatacija ljudi. Sukladno tome nisu iskazali spremnost izdvajanja većih novčanih sredstava za proizvode poduzeća koje etički postupaju prema radnicima, dok su bili spremni podržati etičko postupanje prema životinjama. Uglavnom su cijena, vrijednost, imidž marke i modni trendovi bili generatori njihove modne potrošnje (Carrigan i Attalla, 2001).

Slične je nalaze polučilo istraživanje Joergens (2006) prema kojemu su mladi imali određenu razinu svijesti i znanja o etičkoj potrošnji, ponekad su i kupovali proizvode iz te kategorije te su iskazivali negativne stavove prema modnoj industriji, no etičke stavke u osnovi nisu bile okidači njihove kupovine odjeće. Naime, mladima je prvenstveno bilo stalo do toga da im odjeća stilski odgovara te da se uklapa u njihove želje i potrebe. $S$ time se etička kupovina odjeće pokazala složenijom od kupovine proizvoda poput kave iz lanca pravedne trgovine jer je i sam pojam modnih ukusa obuhvatniji od kriterija prehrambenoga ukusa. Mladima nije bilo problematično kupovanje neetički proizvedene odjeće, jednako kao što im je bila primamljivija veća količina „obične“ robe nego jedan ili dva etička modna primjerka. Zanimljivo je da se i u ovom istraživanju pokazalo da mladi imaju listu etičkih prioriteta na način da su dali prednost kupovini organske hra-

\footnotetext{
2 Iako su svi ovi termini legitimni i sadržajno se u znatnoj mjeri preklapaju, u ovomu radu odlučena je upotreba terminologije brze i etičke modne potrošnje sukladno nizu izvora predstavljenih u teorijskomu poglavlju rada koji su ih doveli u vezu s mladima odnosno, studentima kao populacijom kojom se bavi i ovaj rad. Također valja istaknuti da u literaturi nema jasno definiranih granica između navedenih termina, dapače preklapaju se pa se tako etička moda drži jednim od termina spore mode, kao i eko(loške) mode i nadalje (Aishwariya, 2019). Slijedom navedenoga autori su u ovomu radu primijenili kategorijalni aparat brze-etičke modne potrošnje smatrajući kako njegova teorijska i metodološka širina uputna za istraživanje teme koja je nedovoljno obrađena u hrvatskomu kontekstu i na osnovu čega su moguća daljnja istraživačka rješenja (npr. spora-brza moda, održiva-neodrživa moda, itd.) kao i detaljnija razrada samih terminologija što nije predmet ovoga rada.
} 
ne i namirnica iz pravedne trgovine nad etičkom odjećom, ponajviše jer „hrana direktno utječe na zdravlje, dok neetička odjeća nikome osobno ne šteti“ (Joergens, 2006:365), kao i da što više pažnje pridaju dobrobiti životinja od prava radnika. Osim što su predložili da poduzeća kontroliraju vlade pojedinih država, istakli su i da je dužnost potrošača zahtijevati veću etičnost modne industrije. U konačnici je zaključeno da su cijena i stil presudni elementi mladenačke konzumacije etičke mode, kao i njezine popularizacije u budućnosti (Joergens, 2006).

Neka novija istraživanja su također izvijestila o hibridnosti mladenačke modne potrošnje. U njima je primijećeno da je osviještenost društvenih i okolišnih modnih implikacija oblikovala potrošačke odluke dijela mladih, dok se kod drugih interes u vezi $s$ ovim temama nije konkretizirao u njihovoj kupovni odjeće. Iako se navelo da su mladi u bogatijim zemljama osvješteniji po pitanju etičke dimenzije mode, istaknuto je i da takav interes jača u zemljama u razvoju kao prominentnim modnim tržištima (MacGregor, 2018).

Što se Hrvatske tiče, neke studije su adresirale neznanje i manjak interesa potrošača o društveno odgovornim poduzećima (Srbljinović, 2012), a što je utvrđeno komparativnom analizom modne potrošnje hrvatskih i njemačkih studenata. Uzevši za primjer H\&M internacionalnu marku brze mode koja je poznata i popularna kod hrvatskih i njemačkih studenata, rezultati Bögel i suradnika (2018) potvrdili su da njemački studenti pridaju veći značaj društvenim i okolišnim aspektima pri kupovini njihove odjeće; također su u većoj mjeri smatrali da većina njima bliskih ljudi smatra da trebaju uvažiti takve aspekte pri kupovini odjeće; posjeduju veći stupanj percipirane kontrole tako što pretpostavljaju da imaju veću priliku za uvažavanjem društvenih aspekata te okoliša pri kupovini odjeće u odnosu na hrvatske studente. Uz to, utvrdilo se da su njemački studenti skeptičniji naspram različitih aspekata društvene odgovornosti poduzeća od hrvatskih ispitanika koji su pak iskazali manju razinu znanja o tim temama te su se u većem postotku opredjeljivali za opciju ne znam u odnosu na ispitane njemačke kolegice i kolege (Bögel i sur., 2018).

O dodatnim dimenzijama etičke potrošnje studenata u Hrvatskoj izvijestilo je istraživanje Brstilo Lovrić (2018) prema kojemu je većina ispitanika ponekad ili često kupovala proizvode koji nisu štetni za okolišs, kao i proizvode poduzeća koje poštuju prava radnika. No, po pitanju konzumiranja proizvoda poduzeća koje ne iskorištavaju dječji rad pokazali su se strogo podijeljenima, dok se manji broj izjasnio etičkim potrošačima u pogledu konzumiranja proizvoda koji nisu testirani na životinjama.

Indikativno je da je većina odgovorila da u potrošnji ne vode računa o zaštiti okoliša što je onda dodatno podcrtalo njihovo rasipanje po ispitivanim dimenzijama etičke potrošnje. Isto bi se moglo protumačiti refleksijom njihove nedovoljne upućenosti u samu temu na tragu pojedinih inozemnih istraživanja potrošnje mladih (Pedrozo, 2013). Više o tim temama u kontekstu modne potrošnje studenata u Hrvatskoj informira ovo istraživanje koje će se predstaviti u narednom pasusu, a potom slijedi analiza i interpretacija dobivenih nalaza. 


\section{OPIS ISTRAŽIVANJA}

\subsection{Cilj, metodologija i metoda}

Postavljeni je istraživački cilj ovoga rada istraživanje i opisivanje modne potrošnje studenata u Hrvatskoj koja se, temeljem pregleda literature i referentnih istraživanja, razradila u pet osnovnih tema ili sekcija pitanja. To je prakticirani modni stil u aspektu praćenja trendova i individualizma, percipirani utjecaj na modnu potrošnju, prakticirani modni model $\mathrm{u}$ aspektu kvantitete i kvalitete, upoznatost $s$ etičkim profilom modnih trgovina te preferiranje (ne)etičkoga modnoga proizvoda.

$\mathrm{U}$ istraživanju je korištena kvalitativna metodologija koja se specifično preporuča u slučaju slabije istraženih tema, što jest slučaj s etičkom i brzom modnom potrošnjom mladih i studenata (Bhardwaj i Fairhurst, 2010; Joergens, 2006; Carrigan i Attalla, 2001), posebice u hrvatskomu društvu (Brstilo i sur., 2016). Stoga je ovo istraživanje eksploratornoga tipa kako bi donijelo uvide o slabije istraženoj temi te je aktualiziralo u domaćoj znanosti. Korištena je metoda fokus grupe kojom se izmjenjuju ideje, stavovi i mišljenja u procesu diskusije kako bi se dubinski istražila kompleksna ponašanja i iskustva subjekata uz prednosti brzine, fleksibilnosti i ekonomičnosti, kao i bogatih podataka. Uz interakciju sudionika, ovakva forma grupne diskusije otvara prostor za individualne doprinose što je osobito uputno kod spomenutoga deficita znanstvenih istraživanja na temu (Carrigan i Attalla, 2001:567). Na to je dodatno uputila referentna literatura prema kojoj kvantitativna metodologija, posebno metoda upitnika, nije polučila jasne odgovore ispitanika o etičkim potrošačkim praksama što se pak ostvarilo provođenjem fokus grupe u kojoj se spontana atmosfera pokazala plodnom u stvaranju grupne dinamike i otvorenih iskaza koji su u slučaju upitnika izostali, rezultiravši „konvencionalnim i politički korektnim odgovorima“ (Joergens, 2006:370). Na osnovu toga donesena je odluka o provedbi fokus grupa među mladima, točnije njihovoj specifičnoj podgrupaciji studenata. Naime, u relevantnoj je literaturi prepoznat njihov aktivni interes i modna osviještenost (France, 2007), posebice za konzumiranjem brze mode uz potencijal postajanja vodeće generacije etičkih potrošača (Joy i sur., 2012; Joergens, 2006; Su i Chang, 2018; Cook i Yurchisin, 2017; Joung, 2014). Pojedini istraživači su istaknuli da zbog ograničenih financijskih sredstava i preferiranja trendovske odjeće brza moda igra značajnu socijalizacijsku ulogu upravo u životu studenata koji predstavljaju značajan segment modnog tržišta, a o kojima su dostupne ograničene informacije (Su i Chang, 2018; Joung, 2014). To je također slučaj u hrvatskom kontekstu gdje je općenito malo provedenih istraživanja o modnim potrošačkim praksama mladih i studenata čemu je ovaj rad nastojao doprinijeti.

\subsection{Prikupljanje podataka i istraživačka etičnost}

Potencijalnim sudionicima uputio se poziv za sudjelovanjem u istraživanju na nekoliko internetskih platformi i temeljem osobnih kontakata po kriteriju dobrovoljnosti. S obzirom na okolnosti tekuće pandemije bolesti COVID-19 te riziku održavanja mnogoljud- 
nijih fizičkih okupljanja, sve fokus grupe provedene su putem internetskih platformi Microsoft Teams ili Zoom.

U konačnici organizirane su četiri fokus grupe tijekom svibnja i lipnja 2020. Prosječno vrijeme trajanja fokus grupa je bilo 45 minuta. Realizirani uzorak čini 24 sudionika, od kojih trinaest studentica i jedanaest studenata u rasponu od 19 do 26 godina. Svi sudionici su bili studenti različitih sveučilišnih i stručnih studija na preddiplomskoj, diplomskoj i integriranoj studijskoj razini u Hrvatskoj.

Sukladno etičkim istraživačkim standardima, sudionicima fokus grupa je prethodno prezentirana opća tema i svrha istraživanja uz zajamčenu anonimnost na način da će se $\mathrm{u}$ fazi analize i interpretacije nalaza istraživanja koristiti njihovi pseudonimi, a ne stvarna imena ${ }^{3}$. Istaknuta im je mogućnost odustajanja u bilo kojoj fazi bez posebnog objašnjenja te su pozvani na uključivanje kamera tijekom grupne interakcije, što su svi dobrovoljno prihvatili. U svrhu obrade podataka, sve fokus grupe su zvučno snimane o čemu su sudionici prethodno informirani i za što su dali svoju privolu na samom početku istraživanja.

Fokus grupa sastojala se od pet sekcija pitanja. Prva se odnosila na prakticirani modni stil sudionika istraživanja koji su se opredijelili između kategorije praćenja trendova i njegovanja individualističkoga stila. Druga sekcija pitanja obuhvatila je sudioničko identificiranje glavnoga utjecaja na vlastitu modnu potrošnju. Potom su u trećoj sekciji sudionici opisivali vlastitu modnu potrošnju u aspektu davanja prednosti kvaliteti odnosno, kvantiteti. U četvrtoj su sekciji pitanja bila o poznavanju etičnosti modnih trgovina u kojima su sudionici najčešće kupovali te su se dodatno ispitala njihova saznanja o odnosu tih modnih trgovina naspram radnika, iskorištavanja dječjeg rada i zaštite okoliša. Završna sekcija pitanja bila je o davanju prednosti etičkom ili neetičkom modnom proizvodu u okolnostima identične cijene i dostupnosti.

Tijekom provođenja fokus grupa, istraživačice su vodile iscrpne bilješke o iskazima sudionika i idejama za kodove. Naime, na temelju zvučnih zapisa izrađeni su transkripti koji su analizirani putem otvorenog, aksijalnog i selektivnog kodiranja. Taj je analitički postupak uključio „početno kodiranje, preslagivanje i razvrstavanje podataka, uočavanje sličnosti i njihovo izdvajanje te naposljetku izvođenje zaključaka na temelju konzistentnih obrazaca" (Milas, 2009:582). Izvršeno ručno kodiranje kao primijenjeni način obrade podataka rezultirao je sljedećim kodovima: potrošački stil, utjecaj na potrošnju, kvantiteta ili kvaliteta, etički profil modne trgovine te etički ili neetički proizvodi. Istu logiku slijedi analiza i interpretacija dobivenih nalaza istraživanja u koju su integrirani anonimni iskazi sudionika kako bi njihove originalne misli i termini doprinijeli vjerodostojnosti autorskih zaključaka i transparentnosti samoga istraživanja.

3 Pseudonimi sudionika prve fokus grupe: Jana, Nikolina, Marija, Antea, Božo, Luka.

Pseudonimi sudionika druge fokus grupe: Tea, Marijana, Ivana, Mirko, Paulo, Noa.

Pseudonimi sudionika treće fokus grupe: Tijana, Irena, Luciana, Mladen, Davor, Andrija.

Pseudonimi sudionika četvrte fokus grupe: Eni, Andrea, Katarina, Jurica, Toni, David. 


\section{ANALIZA I INTERPRETACIJA NALAZA ISTRAŽIVANJA}

Sukladno postavljenomu istraživačkomu cilju ispitivanja i opisivanje modne potrošnje studenata u Hrvatskoj, nalazi prikupljeni metodom fokus grupe u ovomu će se dijelu rada analizirati i interpretirati. Slijedi dakle prikaz nalaza o prakticiranomu modnomu stilu sudionika istraživanja, njihovomu percipiranomu modnomu utjecaju, preferiranju kvantitete i kvalitete pri odabiru modnoga proizvoda, poznavanju etičnosti omiljenih modnih trgovina te preferiranju (ne)etičkoga modnoga proizvoda u postavljenim okolnostima identične cijene i dostupnosti.

\subsection{Analiza pitanja o modnomu stilu}

$\mathrm{Na}$ uvodnom pitanju o prakticiranomu modnomu stilu tražila se identifikacija sudionika u kategoriji trendovskoga stila (prate trendove) i individualističkoga stila (njeguju specifični stil). Iako su davali prednost određenom modnomu stilu, sudionici su imali poteškoće u stilskom samoodređenju te su se u većini pokazali sklonima kombiniranju trendovskih i individualističkih elemenata.

Nikolina je tako elaborirala vlastiti stilski individualizam u kontekstu trendovske modne ponude:

„Nije da pratim trendove, biram po nekom svom stilu komade koji su ponudeni svima nama, koji jesu trendi komadi, ali tu opet izabirem ono što pristaje meni, što ja mogu uklopiti u svoj stil i već robu koju imam." (Nikolina)

Slično je bilo i kod Ivane koja se pozvala na posebnost vlastitoga stila uz objašnjenje da je isti baziran na trendovskim trgovinama odakle njena stilska sličnost $s$ drugim djevojkama: „Volim mislit za sebe da se ne oblačim u skladu s trendom i da sam posebna, al' opet kad vidim šta oblačim vidim da se dosta cura tak oblači, vjerojatno se oblačim po trendu pogotovo jer se oblačim u dućanima gdje su stvari u trendu." (Ivana)

U navedenom je iskazu došao do izražaja, u literaturi spominjani, fenomen masovne ekskluzivnosti u vezi s trgovinama brze mode poput Zare (Joy i sur., 2012) koju su sudionici ovoga istraživanja učestalo spominjali. Među njima je bila i Tijana:

"Ja sam samo htjela rec" da onako od tri stvari koje imam na sebi dvije su iz Zare tak da mislim da je to dosta ovaj jasan odgovor i te brze mode izadeš na trg i vidiš još desetero ljudi obučenih isto k'o ti ili sa istim artiklom na sebi. Tak da, da, mislim kao slijedim trendove isto k'o u biti svaka cura danas, ali, ovaj, to dovodi do toga da na kraju svi imamo tri iste stvari iz istog dućana." (Tijana)

Sukladno isticanju tematski srodnih istraživanja (Cook i Yurchisin, 2017; Morgan i Birtwistle, 2009), studentice su se iskazale modno zainteresiranijima od studenata: tako su u kategoriji trendovskih potrošača od njih četvero čak tri bile studentice.

Studenti su pak dominirali u kategoriji potrošačkih individualista: njih petero naspram četvero studentica pri čemu su se pozivali na vlastito modno neznanje („Iskreno nikad nisam znao što se kad nosi u stilu, ne znam, nekih sezona ljeto, jesen, zima, proljeće"); svodeći vlastite modne izbore na funkcionalnost („Više kupujem stvari koje vidim koje bi mi odgovarale i koje mogu skombinirati s nekim drugim odjevnim materijalom"); uz 
napomenu kako nisu uvjetovani okolinom („Niko mi ne može utjecat šta ću ja kupit, šta mi se svidi to uzmem"). Neki su izjavili da ne njeguju poseban stil, već se vode idejom vlastite estetike koja se opire trendovima („Više ono što se meni svidi, nije da pratim neki trend... ne bi rek'o da imam neki stil i ukus"; „Pokušavam biti ne-dio novih trendova, al' nemam neki specifičan stil").

Pri tome je kod modnih individualista primijećen induktivan pristup na način da su vlastiti modni stil predstavljali od osobnih tema prema onim općima vezanima uz modnu industriju, profile trgovina, vršnjačku modnu potrošnju. Kod profiliranih je trendovskih potrošača pak zamijećen deduktivni pristup tako što su se iz općih tema o modnoj potrošnji „spuštali“ na osobniju razinu. Također, potrošački individualisti modne trendove nisu portretirali negativnima per se, koliko su eksplicirali vlastitu nezainteresiranost istima, dok je kod trendovskih potrošača primijećena potreba za dodatnim pojašnjenjima trendovske perspektive u svrhu ograđivanja ili uzmicanja od profiliranja trendovskim potrošačima.

U iskazima se sudionika u osnovi očitovao aktivni pristup modi, bilo da je riječ o četvero trendovskih modnih potrošača, bilo njih devetero $s$ individualističkim odabirom. Pri tome najbrojniji su bili stilski hibridni potrošači, njih jedanaest koji su kombinirali između izgradnje vlastitoga stila i kupovanja u masovno popularnim trendovskim modnim trgovinama. Dobiveni su nalazi dodatno ukazali na postojanje (post)modernoga potrošačkoga sukoba koji su istraživačice Wilska i Pedrozo (2007) dovele u vezu s mladim ljudima koji su u procesu konstruiranja identiteta usmjereni na samopotvrdivanje i uklapanje što objašnjava ovim istraživanjem detektirani spoj sudionikovih istodobnih praćenja modnih trendova i identificiranja individualističkim potrošačima.

\subsection{Analiza pitanja o utjecaju na modnu potrošnju}

S obzirom da je u literaturi istaknuto kako na osobnu potrošnju utječu različiti izvori poput slavnih osoba, reklama, medija i ostalo, dok je drugdje naglašen aspekt samostalnoga potrošačkoga izbora, sljedećom sekcijom pitanja obuhvatili su se odgovori sudionika o identificiranim utjecajima na njihovu modnu potrošnju.

Pri tome su kod većine ili osamnaest sudionika uočena pregovaranja, u prvom redu odbijanjem formaliziranja konkretnih utjecaja na njihov potrošački izbor te (pre)naglašavanjem osobnoga doprinosa. Primjer je toga sudionica Andrea koja se inicijalno pozivala na vlastitu potrošačku samostalnost, da bi onda referirala različite utjecaje poput online modnih blogova:

"Ja sam samostalna u svojoj odluci sta kupujem, al' san isto primijetila da Internet uglavnom utječe na moje odluke. Neki modni blogovi koji često stavljaju neke postove što je došlo novo u dućan i onda stave tu odjeću da ti vidišsta je in, šta je novo došlo. I onda ako se meni nešto svidi, oden u dućan i vidin jel' to zapravo uživo isto k'o na slici i jel' mi se svida $i$ ako mi se svida, kupim, ako ne, ništa." (Andrea)

Irena se također prvo pozivala na vlastitu potrošačku samostalnost spominjući modne utjecaje bez njihovog konkretnoga imenovanja što je interpretirala kao slijepo praćenje trendova: 
„Isto tak generalno nema nitko prevelik utjecaj na to što ću kupit, baš jedna osoba ili jedna stranica ili bilo šta tog tipa nego, ne znam, ak' vidim neku dobru sliku neku osobu koja to zna iznosit tj. iznijet taj kao outfit ili šta već onda će mi doć da to kupim, ali ne sad generalno da netko ima jer onda bi, onda bi, mislim da ako to netko radi onda bi slijepo pratio trendove." (Irena)

Kao najčešći izvor inspiracije u modnoj potrošnji sedmorica je sudionika spomenula društvenu mrežu Instagram te modne profile influencera. Među njima je Tea koja prati modne profile na Instagramu iako nije imenovala konkretne, objašnjavajući da to „nije nešto da toliko utječe, nego cisto zbog ideje u smislu di bi mogla nabavit takvu robu - random slike $i$ strane influencerice, al' čisto zbog ideje“. Slično je i kod Mladena koji je naveo „nemam neku odredenu osobu po kojoj gledam kako bi se oblačio", spomenuvši da na Instagramu zna pogledati odjevne kombinacije nekih muškaraca. I Tijana je odgovorila da ne prati „nikakvu odredenu osobu" te dijeli stil s krugom prijateljica, a i ponekad se javi i influencericama na Instagramu za informaciju o određenom komadu odjeće. Eni pak najveći izvor modnog informiranja i inspiriranja predstavljaju hrvatske Instagram influencerice, točnije s područja Zagreba, jer „barataju sa istim dućanima kao i ja i da mogu otic” na ista mjesta k’o i oni“. Kod petorice sudionika bilo je govora o nesvjesnim utjecajima na njihovu modnu potrošnju. U pravilu su se osvrtali na modni utjecaj bliskih ljudi ili šire okoline, dijelom na modne stilove u filmovima, serijama i na društvenim mrežama, koje im onda ostaju u podsvijesti te filtriraju njihove modne aspiracije. Za primjer je izdvojena izjava sudionika Davida:

„Težim dosta bit individualan, al' kad nešto kupim onda vidim da je okolina nesvjesno utjecala na mene. Dosta ljudi to ima na sebi i onda skužim koliko mi se nesvjesno svidaju neke stvari i utječe mi to na kupovinu." (David)

Dakle, iako je većina sudionika naglasila element potrošačke samostalnosti smatrajući da nitko u bitnome ne utječe na njihove potrošačke odluke, iste su se ispreplele s nizom utjecaja koje su interpretirali kao neobavezne inspiracije ili nesvjesne podražaje što onda sugerira da im pristupaju u aktivnom odnosu naspram jednodimenzionalnoga obrasca uvjetovanja.

\subsection{Analiza pitanja o kvantiteti ili kvaliteti}

Kako bi se ispitao studentski modni model u praksi, treće se pitanje odnosilo na danu prednost principu kvantitete i kvalitete s obzirom da su ti aspekti u referentnoj literaturi dovedeni u kontekst brze mode, odnosno etičke modne potrošnje. Taj se kontekst kod većine pokazao usmjeren na kombiniranje kvantitete i kvalitete varirajući u ovisnosti o određenoj modnoj kategoriji ili artiklu. S time je detektirana lista studentskih modnih ulaganja na način da su spojili kategoriju odjeće poput majica s kvantitetom i jeftinijim cijenama, dok su općenito za kategoriju obuće imali stav da je potrebnija ulaganja u kvalitetu i veću cijenu. Neke njihove izjave na tom tragu:

„Pa robu što se tiče tipa majice i jakne tak hlače i to, ne idem po kvaliteti jer (...) raspadne se ili, jednostavno prepotrošna je roba i pre pre nekako je obično da bi sad to, da bi za to 
odvojila neke više novce i onda će mi se strgat nakon tri dana, ali što se cipela tiče tu gledam kvalitetu. Tako da ovisi ono, o komadu odjeće." (Irena)

"Zavisi što. Za obucu uvijek gledam kvalitetu, a za ovako neke majice ili košulje šta nije toliko skupo gledam kvantitetu, što ću isfurat’ kroz sezonu ili dvije. A opet što se tiče bundi il' tako onda opet gledam kvalitetu jer to neću gledat svake godine." (Eni)

„Izbor robe gledam po kvaliteti, ne da mi se imat hrpu nekvalitetnih stvari i samo gomilat robu, radije pričekam neki popust i kupim neku kvalitetniju stvar. Ajde imam puno majica, to imam jeftino, al' tipa hlače i cipele to gledam da je kvalitetnije." (Toni)

„Bolja mi je kvaliteta nego kvantiteta pogotovo za kapute i cipele. Ove ostale stvari kako nađem, uglavnom kupujem na sniženjima majice, hlače uvijek kupujem po punoj cijeni jer mi je kasnije teško nać" moj broj ili neke koje mi se svidaju. Kvaliteta mi tu i nije važna, al' za cipele $i$ kapute je." (Andrea)

„Meni zapravo ovisi o proizvodu, ako su, ne znam, tenisice ili koledžice onda tu kvaliteta jer to treba dulje trajat, a sad ak' su majice il bijele potkošulje onda kvantiteta." (Noa)

Sedmero sudionika dalo je primat kvantiteti pri čemu su neki poput Antee priznali primamljivost veće količine odjeće za nižu cijenu naspram ulaganja u jedan kvalitetniji i skuplji komad.

„Da je meni isto pretežito kvantiteta bitnija (...) ja ću rade uzet tih 4-5 majica za 50-60 kn, nego kupit jednu košulju za 300." (Antea)

Ostali sudionici s fokusom na kvantitetu to su uglavnom objasnili ograničenim budžetom ("Teško je sad nač neku kvalitetu dok si škvorc"), a u tom su kontekstu istaknuli i poteškoće u opredjeljivanju za princip kvalitete odnosno, kvantitete („Malo mi je teško dat odgovor na to pitanje jer meni ni jedno ni drugo. Kao prvo kvaliteta ne jer zapravo nemam još novaca da si priuštim nešto kvalitetno"), kao i svojevrsno opravdanje neulaganja u kvalitetu („Kada budem zaradio svoj novac, onda planiram kupovati kvalitetnije, a manje"). Upravo se kod takvih sudionika potvrdila opaska nekih autora da upitna kvaliteta brze mode ne utječe na njenu popularnost među mladima (Morgan i Birtwistle, 2009), posebno studentima koji preferiraju jeftinije komade naspram onih skupljih (Su i Chang, 2018). Navedeno potvrđuje i iskaz Andrije po kojemu će se mladenački stilovi bazirani na modernim i jeftinijim potrošačkim izborima moći preorijentirati na kvalitetu tek $s$ financijskim osamostaljenjem:

„Sad idemo na, sad još ganjaš neke svoje stilove i onda to pokušavaš rješavati na neki jeftiniji način, biraš jeftinije opcije jer smo rekli da nemamo novaca, ali kada budem zaradio svoj novac onda planiram kupovati kvalitetnije, a manje, to je neka ideja. Tako da sad kupujes nešto što je onako mladenački simpatično, al' nije kvalitetno." (Andrija)

Pojedini sudionici su se i kritički osvrnuli na opću modnu ponudu današnjice ističući kako ne postoji garancija kvalitete. Prema Tijani to je posljedica tržišta koje ne funkcionira jednako za sve zemlje te je mišljenja da u Hrvatsku dolazi manje kvalitetna roba što onda poništava povjerenje potrošača u odnos cijene i kvalitete.

„Mislim da cijena danas ne diktira nužno i kvalitetu i da su se ljudi na to opekli više puta i da su nekako izgubili povjerenje i u te, ajmo reć, skuplje proizvodače koji su prije bili ono marka kvalitete, tipa Levisice i takve stvari, ovaj dok danas kupiš Levis majicu i raspadne 
ti se nakon dva pranja (...) Tak da jednostavno mislim da više danas ne postoji tol'ka jasna granica izmedu toga pogotovo zato što i ovisi od odredenog proizvođača i u kojoj državi je proizvedeno, nama uglavnom dolazi ono najgore i eto jednostavno su se ljudi više okrenuli toj onda kvantiteti masovne proizvodnje nego davanju novaca na nešto što ti nitko ne garantira da će bit to što turde da je." (Tijana)

Na osnovi pretežnog kombiniranja kvantitete i kvalitete može se sumirati da je modni model sudionika istraživanja bio strateški organiziran, baziravši se na omjeru uloženoga i željenoga u postojećim socioekonomskim ogradama.

Ovaj se nalaz može povezati s nekim ranijim istraživanjima (Joergens, 2006; Carrigan i Attalla, 2001) prema kojima su mladi na različitim potrošačkim poljima pregovarali $s$ onim što im je bitno, odnosno manje bitno uz sklonost sličnim kalkulacijama. Kod dijela sudionika ovoga istraživanja koji su davali prednost kvantiteti kao glavnoj karakteristici brze mode potvrdila se opaska nekih autora da upitna kvaliteta brze mode ne utječe na njezinu popularnost među mladima (Morgan i Birtwistle, 2009), posebno studentima koji daju prednost jeftinijim komadima naspram onima skupljima (Su i Chang, 2018).

\subsection{Analiza pitanja o etičkim profilima modnih trgovina}

$\mathrm{Na}$ središnjem pitanju o poznavanju etičnosti modnih trgovina u kojima najčešće kupuju odjeću, sudionici su pretežno iznosili opća saznanja o neetičnostima modnoga sustava. U pravilu su spominjali globalne modne lance kao što su Nike, H\&M, Zara, kao i zemlje trećega svijeta i Bliskoga istoka s kojima su povezali neekološki, dječji i potplaćeni rad.

Signifikantno je da se gotovo nitko od sudionika nije konkretnije osvrnuo na etičnost modnih trgovina u kojima najčešće kupuju iz čega proizlazi pretpostavka da nisu upoznati s takvim primjerima. Izuzetak je generalno spomenuta Zarina ekološka modna linija i program reciklaže trgovine H\&M koje su dvije sudionice pohvalile zbog etičke prakse. Konkretno je Tijana navela da joj je H\&M „super zbog toga“ te da joj je „lijepo vidjet' i da Zara ima onu kao eco friendly liniju, al' zaboravila sam kako se zove", dok je Luciana odgovorila da je kod nje primarno riječ o kanalu osobne uštede:

„Odlična stvar je H\&M koji se sjetio s tim popustom jer time mi k’o potrošači dobivamo, a ja osobno to ne radim zato što želim reciklirat robu, neg’ čisto zato što eto dobiješ popust, a njima je, njima je jako dobro." (Luciana)

Slično je i s Eni koja vlastitu (ne)informiranost o etičkim korporativnim praksama interpretirala u kontekstu osobne zdravstvene situacije:

"Ja isto nemam neko veliko saznanje kako je to tamo i kakav je materijal u pitanju i trenutno mi nije bitno. Ali u onom trenu kad počnem imat neke zdravstvene tegobe onda vjerujem da ću uključit' mozak i počet’ proučavat' od kakvog je materijala sastavljeno i slično." (Eni) I drugi sudionici su se osvrnuli na materijal odjeće komentiravši uglavnom sastav poliestera ili sintetike u kontekstu neugodnih mirisa „odvratan materijal koji samo se onak” oznojiš dok ga pogledas" i mogućih kožnih oboljenja „kad je nešto onako da mi je neugodno 
da mi ne izbaci nešto po koži". Srodan je stav detektiran i na prethodnom pitanju kod sudionice Marijane koja se nije vodila zaštitom okoliša i brigom o sastavu odjeće, već vlastitom dobrobiti.

„Pa meni osobno je bitan sastav, iako ne mogu reç da mi je svaka stvar u ormaru najsavršenijeg sastava, ali mislim pogledam uvijek da je što prirodnije, ne čak iz tih nekih ekoloških razloga nego kako to utječe na moju kožu. Manje obraćam pažnju na te ekološke razloge." (Marijana)

Kod većeg broja sudionika na ovom pitanju očitovao se (post)moderni potrošački sukob na koji su neki istraživači uputili upravo u kontekstu mladenačke sklonosti kombiniranju praksa i stavova koji se naizgled isključuju (Wilska i Pedrozo, 2007). U ovomu istraživanju radilo se o tome da, iako su sudionici imali opća saznanja o neetičkim praksama pojedinih modnih trgovina te su osuđivali takvo poslovanje, i dalje su u njima kupovali. Među njima bila je Marija koja često zna zanemariti „taj dio“ uz napomenu kako i same Instagram influencerice koje prati rijetko spominju aspekt modne etičnosti; Andrea koja je upoznata s općim modnim praksama te je naglašavala trend ekoloških modnih linija, ali i to da im ne pridaje pozornost; Jane koja je govorila o lošem etičkom kodu Zare, ali i činjenici da i dalje prati njihovu ponudu; Mladena koji nije odobravao neetičnost modnih trgovina, ali je to praktično zanemarivao; Nikoline koja je kritizirala neetičke modne lance poistovjećujući njihovu masovnu proizvodnju odjeće s prehrambenom industrijom, ali je na koncu zaključila kako zbog povoljne cijene brze mode nema modnu alternativu; Ivane koja je navela da je prakse izrabljivanja odbijaju od brze mode, ali je svejedno konzumira. Slijede izjave sudionika istraživanja:

„Nije onako baš lijepo za 'unt', ali nije da mi je to negdje u glavi prilikom kupnje, da razmišljam toliko o tome. Možda kasnije kad čujem kroz neke vijesti ili kad pročitam nešto mi prođe kroz glavu, ali prilikom kupnje rijetko." (Marija)

"Znam da oni izrabljuju $i$ djecu $i$ žene $i$ da rade u nehumanim uvjetima $i$ da uglavnom nisu ekološki osviješteni. Ali za tu ekologiju se nekako u zadnje vrijeme mijenja jer su svi poludili za tim tako da je ovim modnim kućama jako važno da im na etiketama piše, ono, da je eko. A sad da ja gledam kad nesto kupujem na etiketi kako je to napravljeno, je li eko i nisam baš." (Andrea)

„Evo, ja mogu reći da sam bila dosta pristalica (...) za high street modu Zare, no nedavno sam pročitala članak da je zapravo što se tiče njihovog etičkog koda da je dosta loša, odnosno da postoje radnici da rade za minimalac i da su čak bile priče da se koristi dječja radna snaga što me zapravo potaklo na razmišljanje o tom istom brandu jer mislim da, mislim da moda ne bi trebala bit izvor nekakvog ugnjetavanja. Nekako meni sve to ostaje upitno pa o tome se zapravo nadem da nekada baš intenzivno razmišljam, onda s druge strane, ne znam, idem pogledat sta ima novoga." (Jana)

"Naravno da ovako mogu imati odreden stav za to i smatram da nije u redu. Ali prilikom kupnje je onda drugačije." (Mladen)

"Ja obično kupujem u Hङ $M$ i mogu reći da najviše kupujem tamo iako nisam baš sretna zbog toga jer svi ti veliki lanci trgovina kao što su i Ho M, Zara, Terra Nova i New Yorker $i$ ostali - svi oni imaju isti taj loš odnos prema radnicima tj. ta cijela proizvodnja, masovna 
proizvodnja odjeće mi je kao kad pogledate onaj dokumentarac o proizvodnja hrane, manje-više dode na isto. Ali opet mislim da je neizbježno kupovanje u tim dućanima jer baš zbog takve proizvodnje oni nude prihvatljivije cijene. I dok si recimo ne možemo priuštiti neku dizajnersku odjeću domaćih hrvatskih proizvođača, onda smo zapravo ograničeni na H\&M i slične dućane." (Nikolina)

„Izrabljivanje povezujem sovim fast fashion brendovima sto me zapravo ful odbija od njih $i$ baš rijetko kupujem tamo jer ne postoji razlog da je ta roba toliko jeftina, a da je ljudi rade za normalnu plaću. Ne mogu reć" da ne kupujem u tim dućanima, al' u zadnje vrijeme se trudim što manje baš iz tog razloga." (Ivana)

Iz potonja dva iskaza i na ovom je pitanju isplivao značaj cijene, ali u percepciji modne etičnosti tako što su sudionici izjednačili jeftiniju odjeću i neetičke trgovine odnosno, skuplju odjeću i etičke trgovine, posebno u slučaju dizajnerskih marka.

Među sudionicima bilo je i onih koji su se na neetične prakse modnog sustava osvrnuli sa skepsom, bilo kao na "priče“", „legende "ili „predrasude“, upućujući na upitnost izvora informacija (,Sad, jel’ to neki lobiji, jel' to stvarno istina, u kakvim su uvjetima ta djeca, ti ljudi, ekološke mjere kakve su ja nemam pojma i nemam izvor kojem vjerujem") i posljedično vlastitu zbunjenost („Uvijek ima nekih članaka koji kažu jedno, drugi onda kažu drugo i nekako se sve to pogubi"). Po drugima je pak modna etičnost stvar globalnog trenda ("globalni stav danas da je ekologija pitanje broj jedan") pa čak smatraju zastarjelima trgovine bez ekoloških linija, što po jednom sudioniku „odlazi u neko veće pretjerivanje“. Iz dobivenih je nalaza istraživanja rezonantno da sudionici nisu bili konkretnije upoznati s etičkim profilom modnih trgovina u kojima su najčešće kupovali, međutim čak i kod manjine koja je spominjala opće neetičnosti modnoga sustava nije došlo do povezivanja s praktičnom razinom, baš kao što su neka srodna istraživanja zabilježila (Joergens, 2006; Carrigan i Attalla, 2001). Modna potrošnja sudionika ovoga istraživanja utoliko je prvenstveno funkcionirala u kontekstu njihovih estetskih i stilskih preferencija. No, valja naznačiti i da je petero sudionika iskazalo spremnost mijenjanja vlastitih potrošačkih praksi sukladno saznanjima o modnim neetičnostima. Neki od njih su istaknuli „Kad bi imala neke pouzdanije informacije vjerojatno bi izbjegavala takve dućane“ ili „Da otkrijem da izrabljuju djecu ili ljude da bi odustala možda od tog brenda kojeg kupujem". Iako u manjini, kod njih je uočen odmak od dominantnoga zastupanja vlastite dobrobiti (dobivanje popusta, potencijalne zdravstvene tegobe, neprivlačni materijali) na širi, društveni kontekst i reperkusije vlastite modne potrošnje.

\subsection{Analiza pitanja o etickim ili neetičkim proizvodima}

Kako bi dubinski ispitali etičku potrošačku motivaciju sudionika istraživanja, postavljeno im je pitanje o odabiru etičkoga ili neetičkoga modnoga proizvoda u okolnostima identične cijene i dostupnosti s obzirom da su ti aspekti u literaturi istaknuti jednima od ključnih barijera mladenačke etičke potrošnje (Joergens, 2006). Kao i u slučaju prethodnih sekcija pitanja, dobiveni su nalazi bili slojeviti.

Iako se nijedan sudionik nije eksplicitno odlučio za neetički proizvod, trojici, ujedno i najmanjem broju sudionika iz takozvane skupine nezainteresiranih, bilo je "svejedno" 
jer im etičnost "ne predstavlja neku ulogu pri odabiru“. Situacija se nadalje pokazala dvojbenom kod devetero prozvanih etičkih pregovarača koji su postavili određene uvjete za odabir etičkih proizvoda i nešto brojnijih (jedanaest) proetičara koji su se u postavljenom kontekstu nedvojbeno opredijelili za etički proizvod ${ }^{4}$. Potonji su istaknuli više obrazloženja vlastitoga etičkoga odabira među kojima je artikulirana ljudskost i želja za činjenjem općega dobra kako nitko ne bi ispaštao zbog tuđih potrošačkih odabira, baš kao što je Antea obrazložila:

„Zašto bi ispaštao netko za nešto što sad ja želim, a ne moram nosit' ili imat?? Tako da definitivno bih birala nešto za što znam da je napravljeno u normalnim uvjetima rada, a ne gdje su ljudi izrabljivani." (Antea)

Osim afirmativnih razloga, proetički orijentirani sudionik Božo svoj je odabir etičkog proizvoda povezao s otporom ugnjetavačkom modnom i tržišnom sistemu što je potvrdilo uvodnu tezu Lipovetskog (2008) kako je etička potrošnja vrsta potrošačkog bunta protiv sistema:

„Prije bih kupovao etički čiste stvari nego one koji nisu (...) Po mom mišljenju to predstavlja neku vrstu otpora prema cijelom tom sistemu koji ugnjetava ljude, koji zagaduje okoliš $i$ slično, tako da uvijek bih odabrao to nego etički onečiććenu robu." (Božo)

Skupina prozvanih etičkih pregovarača bila je neodlučnija te su u postavljenim okolnostima rezonirali vlastite „uvjete“ za odabir etičkog proizvoda. Kod većine prevladao je izbor temeljen na osobnim preferencijama. Među njima su bile Irena i Luciana koje su vlastite dvojbe primarno usmjerile na dinamiku (ne)sviđanja, dok su etički razlozi bili sekundarni: "Pa ako je isto onda ću kupit' etički, a ako nije isto kupit ću ono koje mi se više svida. Mislim o tome pričamo cijelo vrijeme da kupujemo ono što nam se više svida $i$ vizualno, a ne sad kak'se on proizvodi." (Irena)

„Ako je identično mislim normalno da ćemo uzeti etičnu stvar (...) Sad šta mi se najviše svida to bi bilo, prevagnulo. Jer kao što sam rekla u prethodnom pitanju, nije da previše obraćam pažnju na to što je i kako je etično." (Luciana)

Uz istaknuti kriterij izgleda i kvalitete, sudionici su se pozivali na nedostatak informacija i manjak povjerenja u modni sustav te posljedičnu zbunjenost na razini vlastitih izbora. Navedeno se eklatantno očituje u Andrijinom stavu:

"Ukoliko ja znam da je to tako, naravno da ću ić u ovu koja mari. Ali to se danas ne zna. Šta, ovi će reć mi marimo, a ovi ne, mi ne marimo. Tako da to baš trebaš pratit, ove sve zapravo situacije i, i vjerovati tome što si pročitao na nekim medijima i ostalo." (Andrija) Uz nepovjerenje i nesigurnost, kod nekih sudionika poput Tijane bila je prisutna racionalizacija i poopćavanje etičkih praksi i proizvoda:

„Ovo je sad ono hipotetski - da ti netko kaže ovo tu je izradeno od radne snage koja je plaćena toliko i toliko i imaju super životne uvjete bla bla, a ovo su izradili, izradila izrabljena djeca - nitko neće uzet stvar koju su radila izrabljena djeca kad se tak posloži, ali vjerojatno svaki dan nesvjesno biramo te iste stvari pored ovih drugih." (Tijana)

$4 \mathrm{Na}$ ovomu se pitanju jedna sudionica istraživanja nije očitovala. 
Zaključno, sudionici istraživanja pretezali su prema izboru etičkog proizvoda te se nitko od njih nije eksplicitno odlučio za neetički proizvod. Potvrđujući važnost čimbenika cijene i dostupnosti, pojedinci su kalkulirali između odabira etičkog i neetičkog proizvoda dajući na važnosti kriterijima privlačnosti modnoga proizvoda. Detektirana barijera studentskim etičkim izborima bila je nedovoljna informiranost i nepovjerenje u modni sustav. S time je potvrđena izjava Tallontire i suradnika (2001) kako etičke potrošače od onih neformiranih razlikuje potreba za dodatnim poticanjima etičke prakse. Ta se potreba u ovom istraživanju prvenstveno odnosila na veću studentsku edukaciju i medijsku pokrivenost ovih tema.

\section{ZAKLJUČAK}

Ovaj se rad zasniva na analizi studentskih stavova i praksi u domeni modne potrošnje. Temeljem provedenoga kvalitativnoga istraživanja metodom fokus grupe, postavljeno je nekoliko sekcija pitanja kako bi se doznalo profilira li se modna potrošnja studenata u Hrvatskoj u kontekstu praćenja trendova i individualizma, percipiranoga utjecaja na potrošnju, aspekta kvalitete i kvantitete, poznavanja etičkih profila trgovina te davanja prednosti etičkom ili neetičkom proizvodu. Navedene sekcije pitanja proizašle su iz referentnih istraživanja i teorijskoga okvira visoke modernosti ili postmodernosti koji je doveden u vezu $s$ različitim ambivalencijama. To se potvrdilo ovim istraživanjem te se u gotovo svim ispitivanim područjima modna potrošnja studenata pokazala hibridnom i slojevitom.

Tako su se sudionici ovoga istraživanja ustručavali stilski odrediti u kategorijama praćenja modnih trendova i individualizma te su u većini bili skloni njihovomu kombiniranju što je rezultiralo hibridnim modnim praksama. Sličan zaključak proizašao je i iz sekcije pitanja o poznavanju (ne)etičkoga profila omiljenih modnih trgovina. Iako su složno osuđivali neetička poslovanja pojedinih modnih trgovina, priznali su da i dalje tamo kupuju. Dakle, studentska saznanja o neetičnostima modnoga sustava nisu se reflektirala na razinu njihove prakse što su na različite načine argumentirali, između ostaloga i nepovjerenjem u modni sustav te medijskim plasiranjem oprečnih informacija. Odatle njihova strategija zanemarivanja, racionalizirana stavovima: „teško je vjerovat' u vjerodostojnost tih informacija koje dobivamo tako da zasad to nema utjecaja na moje odluke“; "ko će o svemu razmišljat"; „zasad ne znam nešto točno pa kupujem sve“; „uzimam u povjerenju da su te kompanije etične, sad jesu il' nisu nemam dovoljno informacija“. Slijedom navedenih iskaza može se nadalje promišljati jesu li neznanje i nepovjerenje u etičke kategorije adaptivne životne strategije studenata koje im služe kao svojevrstan alibi za nedjelovanje ili je u pozadini neki drugi mehanizam. Svakako valja primijetiti da su se na ovom pitanju ustručavali osobnije govoriti pa su nerijetko generalizirali sve modne trgovine uz artikuliranje vlastitoga neznanja u prizmi općega, društvenoga neznanja i nezainteresiranosti za ovu temu.

Slojevitost studentske modne potrošnje nadalje je reflektirao detektirani paradoks masovne ekskluzivnosti na način da su u većini sami sebe okarakterizirali modnim individualistima na čiju potrošnju nitko ne utječe, dok su u isti mah bili skloni kupovanju u 
masovno popularnim trendovskim trgovinama brze mode, odakle proizlazi njihova stilska sličnost $s$ drugim mladima. Takav se stilski individualizam onda isprepleo $s$ popularnom ekskluzivnosti producirajući, kolokvijalno rečeno, kolektivne modne individualce. Uz to indikativno je da se nitko od sudionika nije pozvao na konkretne modne uzore ili utjecaje, ističući kako je njihov izbor samostalan i individualan. Međutim, iako ih nisu konkretizirali, znatan je dio sudionika spomenuo općenito praćenje modnih profila influencera na društvenoj mreži Instagram, nesvjesne utjecaje iz okoline te različite medije, objašnjavajući njihov utjecaj „čisto zbog ideje“ ili kao neobavezne „inspiracije“. Na taj je način u cjelini očitovano da su sudionici vlastite modne prakse odmicali od konteksta pasivnih primatelja, prema kontekstu kritičnih i selektivnih modnih potrošača koji zauzeto rade na vlastitim biografijama.

Hibridnost mladenačke modne potrošnje pokazana je i u odnosu kvantitete i kvalitete koju su sudionici uglavnom vješto kombinirali. Razvivši listu modnih prioriteta ili ulaganja, za određenu im je kategoriju odjeće, poput majica, bila važnija kvantiteta i jeftinija cijena, dok im je pri izboru obuće presudila kvaliteta. Pri tome valja istaknuti kako je dio sudionika davanje prednosti kvantiteti racionalizirao vlastitom socioekonomskom situiranosti za koju su smatrali da njihove modne izbore uvjetuje isplativijim rješenjima u okvirima brze mode. Međutim, imajući u vidu da većina sudionika nije imala konkretnija saznanja o neetičnostima modnoga sustava niti trgovina u kojima kupuju odjeću te su u pravilu određene etičke prakse povezivali s vlastitom dobrobiti (kao kanal financijske uštede ili povoljnoga djelovanja na vlastito zdravlje), za pretpostaviti je kako njihova modna potrošnja u cjelini nije bila plod informiranoga izbora, već određene inercije na tragu istaknutoga fenomena masovne ekskluzivnosti. U pogledu toga se pokazana studentska usmjerenost na modnu kvantitetu može ogledati dvojako, kao produkt socioekonomske uvjetovanosti te kao refleksija etičke neinformiranosti odnosno, nezainteresiranosti.

Pitanjem o davanju prednosti (ne)etičkom proizvodu u uvjetima jednake dostupnosti i cijene ovim je istraživanjem opetovano podcrtana hibridnost studentske modne potrošnje. Oni su, naime, ponudili višestruke odgovore: nezainteresiranima je bilo svejedno o kakvom proizvodu se radi, prozvani su se proetičari nedvojbeno opredijelili za etički proizvod, dok su takozvani pregovarači artikulirali vlastite uvjete za odabir etičkoga proizvoda pri čemu je bilo ključno da im se proizvod sviđa, a tek sekundarno njegova etička atribucija. U osnovi se iz svih istraživačkih nalaza može podcrtati potreba za edukacijom studenata o socijalnim reperkusijama brzoga modnoga izbora te potencijalima etičke potrošnje. U vezi s tim, studenti bi kao nositelji novih društvenih trendova mogli znatno doprinijeti općoj društvenoj senzibilizaciji za ovom temom promičući modnu osviještenost iz pukoga konzumerističkoga diskursa u praktičnu društvenu vrijednost. Zaključno smatramo kako je studentska hibridna modna potrošnja adresirala kontekst (post)modernosti koji reproducira opću klimu nesigurnosti, usmjeravajući pojedince na različite životno-stilske strategije. One su po brojnim društvenim analitičarima uklopljene u suprotstavljene procese koji otežavaju izbor na svakodnevnoj razini istodobno ga prebacujući na pojedinačnu obvezu i odgovornost. Slijedom toga životni stil postaje 
izazovan poduhvat koji traži kontinuirano reflektiranje nadgledanje vlastite biografije prema lokalnim i globalnim utjecajima, novim i često oprečnima (sa)znanjima, referirajući misao Baumana (2009) kako je posljedica suvremenog života zbunjenost pojedinca prisiljenog živjeti u stanju stalne ambivalentnosti ili onomu što Giddens (1991) prepoznaje kao dvostruku i rizičnu modernost. Ovo je istraživanje krenulo od pretpostavke da upravo takva sociokulturna klima profilira potrošačku kombinatoriku studenata u dijapazonu brze i etičke mode, kvantitete i kvalitete, individualizma i praćenja trendova, potrošačke samostalnosti i uvjetovanosti različitim utjecajima. I doista, na svim se tim poljima očitovalo da studenti nastoje, u uvjetima postojeće ponude, informiranosti i socioekonomske situacije, pronaći optimalan izbor, ma kako ambivalentan bio. Njihove modne prakse štoviše funkcioniraju kao životne strategije u kolopletu (post)modernosti, slojevite kao i sama društvena stvarnost.

Naposlijetku, navedene autorske zaključke treba sagledati u okviru ograničenja provedenoga istraživanja. $S$ obzirom da se radilo o kvalitativnom tipu istraživanja na bazi prigodnoga uzorka, dobiveni nalazi nisu poopćivi na mlade odnosno, studente u Hrvatskoj. Zbog toga je ovo istraživanje eksplorativnoga tipa poslužilo za aktualizaciju slabo obrađenih tema u društvenim znanostima, napose sociologiji, naznačivši određene teme za buduća istraživanja. To je posebno slučaj $s$ ulogom edukacije o socijalnim reperkusijama etičke i brze mode čije bi istraživanje na reprezentativnom uzorku studenata i mladih u drugačijem teorijskom okviru moglo doprinijeti novim spoznajama u znanosti i informiranju društvene javnosti.

\section{LITERATURA}

Aishwariya, S. (2019). Fast Fashion vs Slow Fashion. Fibre2Fashion: World of Garment-Textile-Fashion, Studeni 2019. URL: https://www.fibre2fashion.com/industry- article/8460/fast-vs-slow-fashion (14.11.2020.)

Barnes, L. i Lea-Greenwood, G. (2006). Fast fashioning the supply chain: Shaping the research agenda. Journal of Fashion Marketing and Management, 10(3): 259-271.

Bauman, Z. (1993). Modernity and Ambivalence. Cambridge: Polity Press.

Bauman, Z. (2009). Postmoderna etika. Zagreb: AGM.

Bhardwaj, V. i Fairhurst, A. (2010). Fast fashion: response to changes in the fashion industry. The International Review of Retail, Distribution and Consumer Research, 20(1): 165- 173.

Bögel, P. M., Brstilo Lovrić, I., Bekmeier-Feuerhahn, S. i Sippel, C. S. (2018). Socio-cultural differences in understanding and development of corporate social responsibility in Germany and Croatia. U: Tench, R., Jones, B. i Xiuping Sun, W. (ur.), The Critical State of Corporate Social Responsibility in Europe. Critical Studies on Corporate Responsibility, Governance and Sustainability (str. 161-178). Bingley: Emerald Publishing Ltd.

Bohra, K. L. i Jose, A. M. (2019). A study on fitness lifestyle among the youth: analysis of its impact through Instagram. International Journal of Scientific Research and Review, 7(5): 610-648. 
Brstilo Lovrić, I. (2018). Potrošnja i nove tehnologije među mladima u Hrvatskoj: analiza potrošačkih stilova i praksi studenata Sveučilišta u Zadru i Zagrebu. Doktorska disertacija. Zadar: Filozofski fakultet u Zadru.

Brstilo, I., Krešić, I. i Vučković, K. (2016). O prijeporima etičke potrošnje iz društvenog rakursa. Socijalna ekologija, 25(3): 289-310.

Carrigan, M. i Attalla, A. (2001). The myth of the ethical consumer - do ethics matter in purchase behaviour. Journal of Consumer Marketing, 18(7): 560-577.

Cook, S. C. i Yurchisin, J. (2017). Fast fashion environments: consumer's heaven or retailer's nightmare? International Journal of Retail \& Distribution Management, 45(2): 143- 157.

de Perthuis, K. i Findlay, R. (2019). How Fashion Travels: The Fashionable Ideal in the Age of Instagram, Fashion Theory, 23(2): 219-242.

Dockrill, M. (2020). How Ethical Is Zara? Good on you, 28. kolovoza 2020. URL: https://goodonyou.eco/how-ethical-is-zara/ (09.05.2020.)

France, A. (2007). Understanding Youth in Late Modernity. London: Open University Press.

Giddens, A. (1991). Modernity and Self-Identity. Self and Society in the Late Modern Age. Cambridge: Cambridge University Press.

Hall, S. M. (2011). Exploring the 'ethical everyday': An ethnography of the ethics of family consumption. Geoforum, 42(6): 627-637.

Joergens, C. (2006). Ethical fashion: myth or future trend? Journal of Fashion Marketing and Management, 10(3): 360-371.

Joung, H. M. (2014). Fast-fashion consumers' post-purchase behaviours. International Journal of Retail \& Distribution Management, 42(8): 688-697.

Joy, A., Sherry, Jr. J. F., Venkatesh, A., Wang, J. i Chan, R. (2012). Fast fashion, sustainability, and the ethical appeal of luxury brands. Fashion Theory, 16(3): 273-295.

Laudette, C. L. i Dowsett, S. (2019.) Zara owner Inditex reports strong profit growth, shares at year highs. Reuters, 11. prosinca 2019. URL: https://www.reuters.com/ article/us-inditex-results/zara-owner-inditex-reports-strong-profit-growth-sharesat-year-highs- idUSKBN1YF0MB (02.04.2020.)

Lewis, T. (2012). Ethical Consumption. U: Paul James i Nevzat Soguk (ur.), Annual Review 2012: Global Cities (str. 67-71). Carlton: RMIT University.

Lipovetsky, G. (2008). Paradoksalna sreća. Ogled o hiperpotrošačkom društvu. Zagreb: Biblioteka Antibarbarius.

MacGregor, A. (2018). Is youth engagement the key to creating a circular fashion industry? London: InSpring i JA Worldwide.

Milas, G. (2009). Istraživačke metode u psihologiji i drugim društvenim znanostima. Jastrebarsko: Naklada Slap.

Morgan, L. R. i Birtwistle, G. (2009). An investigation of young fashion consumers' disposal habits. International Journal of Consumer Studies, 33(2): 190-198.

Pedrozo, S. (2013). Consumption, youth and new media: The debate on social issues in Brazil. Turku: Turku School of Economics.

Remy, N., Speelman, E. i Swartz, S. (2016). Style that's sustainable: A new fast-fas- 
hion formula. McKinsey \& Company, 20. listopada 2016. URL: https://www. mckinsey.com/business-functions/sustainability/our-insights/style-thats- sustainable-a-new-fast-fashion-formula (02.04.2020.)

Ritzer, G. (1999). Mekdonaldizacija društva. Istraživanje mijenjajućeg karaktera suvremenog društvenog života. Zagreb: Naklada Jesenski i Turk.

Robertson, L. (2020). How Ethical Is H\&M? Good on you, 30. rujna 2020. URL: https://goodonyou.eco/how-ethical-is-hm/ (09.05. 2020.)

Roubík, H. i Mazancová, J. (2017). Do young consumers care about ethics ? Influence of DEAR and GDI on buying preferences - A pilot study. Agronomy Research, 15(1): 270-279.

Srbljinović, M. (2012). Utjecaj društvene odgovornosti poduzeća na ponašanje potrošača u Hrvatskoj. Zbornik Ekonomskog fakulteta u Zagrebu, 10(2): 161-180.

$\mathrm{Su}$, J. i Chang, A. (2018). Factors affecting college students' brand loyalty toward fast fashion: A consumer-based brand equity approach. International Journal of Retail \& Distribution Management, 46(1): 90-107.

Tallontire, A., Rentsendorj, E. i Blowfield, M. (2001). Ethical consumers and ethical trade: a review of current literature. Natural Resources Institute Policy Series 12. London: University of Greenwich.

Wilska, T. A. i Pedrozo, S. (2007). New technology and young people's consumer identities: A comparative study between Finland and Brazil. Young, 15(4):343-368. 


\title{
IN THE CIRCUIT OF (POST)MODERNITY: STUDENTS' PERSPECTIVE ON FAST AND ETHICAL FASHION CONSUMPTION
}

\author{
Ivana Brstilo Lovrić, Marta Šuća and Paula Zujić
}

\begin{abstract}
This research aims to fill the gap in the existing literature on fashion consumption by looking at the Croatian context. As referential literature shows that students have particularly active fashion interests, our qualitative research focused on the student population by using the method of focus groups with a total of 24 students over 4 meetings in mid-2020. The general goal was to examine students' fashion practices in their everyday lives, with the emphasis on the principles of fast and ethical fashion consumption, to determine their dominant profiles/models. Although the research participants were not provided with specific information about the (non)ethical practices of fashion stores and generally consumed fast fashion, they were open to ethical products, believing that fashion should not be a source for the oppression of the actors involved. The findings also revealed the existence of a (post)modern consumer conflict, with participants characterizing themselves as fashion individualists who followed the fashion trends (most were inspired by fashion content from their surrounding as well as various media and social networks), while at the same time denying any influence on their consumer choices. In developing their lists of fashion investments, they balanced between quality and quantity, often revealing themselves as mass exclusivists. The demonstrated complexity and hybridity of students' fashion consumption was interpreted in the context of (post)modern lifestyle ambivalence and we indicate the need for better education and social engagement of students on this topic.
\end{abstract}

Keywords: fashion consumption, fast fashion, ethical fashion, students, Croatia, (post)modernity

\section{IM GEWIRR DER (POST)MODERNITÄT: SCHNELLER UND ETHISCHER MODEVERBRAUCH AUS DER STUDENTENPERSPEKTIVE}

\section{Zusammenfassung}

Ivana Brstilo Lovrić, Marta Šuća und Paula Zujić

Diese Arbeit thematisiert den nicht genug erforschten Modeverbrauch im kroatischen Kontext. Da in der Referenzliteratur ein aktives Interesse der Studenten an der Mode hervorgehoben wurde, wurden Mitte 2020 vier Male 24 Studenten in eine qualitative Forschung mit der Methode der Fokusgruppe einbezogen. Ein allgemeines Ziel war es, Modepraxen von Studenten in ihrem Alltag zu erforschen, besonders hinsichtlich der Prinzipien des schnellen und ethischen Modeverbrauchs, um festzustellen, nach welchem Modell sie profiliert werden. Obwohl die Forschungsteilnehmer über keine konkreten Erkenntnissen über die (nicht) ethischen Praxen von Modegeschäften verfügten und in der Regel schnelle Mode konsumierten, haben sie sich ethischen Produkten gegenüber offen gezeigt und fanden, dass Mode keine Unterdrückungsplattform der involvierten Akteure sein sollte. Es wurde das Bestehen eines (post)modernen Verbraucherkonflikts belegt, indem die Teilnehmer sich selbst als Modeindividualisten sahen, aber zugleich den Modetrends folgten und dabei Einflüsse auf die eigene Verbraucherwahl negierten, die meisten inspirierten sich von Modeinhalten auf sozialen Netzwerken, aus der Umgebung und aus verschiedenen Medien. Sie haben Qualität und Quantität kombiniert, nicht selten als Anhänger der Massenexklusivität. Die gezeigte Stratifizierung und Hybridität des studentischen Modeverbrauchs wurde schließlich im Kontext der (post)modernen Ambivalenz des Lebens und des Stils interprätiert und es wurde darauf hingewiesen, dass bei Studenten ein Bedarf nach einer besseren Eduzierung und mehr Einsatz hinsichtlich dieses Themas besteht.

Schlüsselwörter: Modeverbrauch, schnelle und ethische Mode, Studenten, Kroatien, (Post)modernität 